\title{
Chronic exposure to MDMA (ecstasy)induces DNA damage, impairs functional antioxidant cellular defenses, enhances the lipid peroxidation process and alters testes histopathology in male rat. *Nadia Gamal Zaki, ** Laila Abdel Kawy
}

Narcotic Research Department, the National Center for Social and Criminological Research, Cairo, Egypt

\begin{abstract}
:
Background :

3,4-Methylenedioxymethamphetamine (MDMA or "ecstasy") is consumed mainly by young population. For this reason, it is especially relevant to take into consideration the effects on the reproductive system. The influence of MDMA on the fertility and reproduction of the male rat was assessed in this study.

Material and methods: MDMA was administered orally at $0 \mathrm{mg} / \mathrm{kg}$ (control), 10 and 30 $\mathrm{mg} / \mathrm{kg}$ to male rats for $15,30,45$ consecutive days followed by 15 days withdrawal. Hormonal, biochemical, histological and testicular were evaluated in the rats. The present study aimed to investigate if daily oral administration of ecstasy at low doses $(10 \mathrm{mg})$ for 45 days has any deleterious effects on reproductive functions of male rats. Animals were randomly divided into four groups of ten rats each, assigned as control rats, or(0mg ecstasy), rats treated with $10 \mathrm{mg}$ ecstasy for, $(15,30,45)$ days, rats treated with $30 \mathrm{mg} / \mathrm{kg}$ body weight ecstasy for(,15,30,45)days by oral gavage. The third group(45 days) was followed by 15 withdrawal period(W15).

Results: The activities of superoxide dismutase, catalase, glutathione reductase and glutathione peroxidase in testicular homogenate were decreased while the levels of lipid peroxidation increased significantly in the treated rats as compared with the corresponding group of control animals. In group $30 \mathrm{mg}$, only, arachidonic acid was significantly elevated in the testicular homogenate while linoleic acid was decresed when compared to control. Testis DNA fragmentation was observed in $30 \mathrm{mg}$ group, but not $10 . \mathrm{mg}$. It is concluded that low doses of ecstasy exposure $(10 \mathrm{mg} / \mathrm{Kg})$ had moderate detrimental effects on reproductive organ system and more severe effects are likely to be observed at higher dose levels. These results indicate that ecstasy is directly toxic to primary Leydig cells, and that the decreased percentage of normal cells and the increased level of DNA damage in ecstasy -exposed Leydig cells may be responsible for decreased testosterone secretion. The results suggested that graded doses of ecstasy elicit depletion of antioxidant defence system and induce oxidative stress in testis of rats.
\end{abstract}

In conclusion: the adverse effect of ecstasy on male reproduction may be due to induction of oxidative stress.

Key words:MDMA(ecstasy),testes,free fatty acids,oxidant/antioxidant status

\section{Introduction:}

3,4-ethylenedioxymethamphetamine (MDMA, Ecstasy) is a psychoactive drug with significant abuse liability and neurotoxic potential (1). A recent national survey indicates that recreational MDMA use may be once again on the rise (2). Ecstasy" (MDMA) and related drugs are amphetamine derivatives that also have some of the pharmacological properties of mescaline. They have become popular with participants in "raves," because they enhance energy, endurance, sociability and sexual arousal. This vogue among teenagers and young adults, together with the widespread belief that "ecstasy" is a safe drug, has led to a thriving illicit traffic in it(3,4). MDMA is almost taken by mouth and is prepared as single-dose tablets for this purpose, though the great majority consist of a single active drug. The typical dosage range of MDMA for recreational use varies from $50 \mathrm{mg}$ to 150 $\mathrm{mg}$, but the amount per tablet in different batches of tablets may vary 70-fold or more, from almost zero to well over 100 mg ( 5,6,7). MDMA and the other ringsubstituted amphetamine derivatives act by increasing the net release of the monoamine neurotransmitters (serotonin, noradrenaline and, to a smaller extent, dopamine) from their respective axon terminals. MDMA does not act by directly 
releasing serotonin but, rather, by binding to, and thus blocking, the transporter involved in its reuptake. It is clear, however, that the increase in the net release of serotonin (and possibly dopamine) is the major mechanism of action underlying the distinctive mental effects of MDMA, whereas the increased release of noradrenaline is mainly responsible for the physical effects that it shares with amphetamine $(8,9)$.

The reported effects of MDMA vary according to the dose and the frequency and duration of use. In general, The desired effects for which MDMA is used are closely similar to those that account for the continuing popularity of the other amphetamines. Physically, it produces a marked increase in wakefulness, endurance and sense of energy, sexual arousal, and postponement of fatigue and sleepiness. The accompanying psychological effects are described as a sense of euphoria, well-being, sharpened sensory perception, greater sociability, extraversion, heightened sense of closeness to other people, and greater tolerance of their views and feelings $(10,11,12,13)$. Although male infertility is well documented as a result of exposure to numerous toxicants, the effects of ecstasy on male reproduction and fertility are less well known, $(14,15,16)$.

\section{Material and Methods:}

\section{Chemicals and kits:}

All chemical used in the present study were purchased from BDH Chemical Ltd., Pools (England). All utilized kits were obtained from BioMerieux laboratory reagents and products (France) and Boehringer, Mannheim GmbH (Germany).

2. Ecstasy: drug was obtained in tablets from the Antinarcotic General Administration, Ministry of Internal Affairs,Egypt.

\section{3-Animals:}

100 male white albino rats of Sprague Dawley weighed about (100-150 g body wt.) were obtained from experimental animal house, Helwan, Egypt. Animals were maintained on stock diet in the form of pellets having the following composition: protein $(18.8 \mathrm{w} / \mathrm{w})$, barley $(37 \% \mathrm{w} / \mathrm{w})$, corn $(15 \% \mathrm{w} / \mathrm{w})$, salt and vitamins mixture $(29.2 \%$ $\mathrm{w} / \mathrm{w})(17)$. All animals were normally and healthy. The animals were divided into three groups one group served as control(20 rats) and the other two groups served as treated(40 rats in each group) and injected by 10and 30 $\mathrm{mg} / \mathrm{kg}$ body weight of ecstasy (7) (chronic dose) for 15, 30 and 45 days, The THIRD SUBGROUP 45-day treatment was followed by 15 days of withdrawal (w15). These daily doses in relation to their respective therapeutic effective doses were calculated according to Paget and Barnes (18)for species interconversion of dosage. All animals were scarified after 30 minutes from the last administration, testis were excised and divided into two parts. One part kept in formalin for histological examination and the other part homogenized for biochemical analysis determination.

\section{Investigated parameters: 1-Experimental Protocol:}

Rats were divided into three groups $(n=10)$. Groups were treated as followed: Normal (N); received saline); treated group 1; received a single dose $(10 \mathrm{mg} / \mathrm{kg}$, orally); used for 15,30,45 days. Treated group (II)was administrated orally (by gavages) $30 \mathrm{mg} / \mathrm{Kg}$ ecstasy (ECS);for 15,30,45 days. The 45subgroup in each group was left for 15 days without treatment(withdrawal group).

\section{2--Lipids extraction:}

One testis from each rat was immediately removed after sacrificing, preserved in cold saline solution $(10 \mathrm{ml})$, homogenized for 5 minutes by electric homogonizer and centrifuged at 3500 r.p.m for 15 minutes. The pellets were then washed twice with $5 \mathrm{ml}$ of cold saline, the supernatant was for oxidant/ antioxidant determination. An equal volume of $10 \%$ cold TCA was added to the pellets and centrifuged for 10 minutes at 600 r.p.m. The residues were then washed twice with $5 \%$ cold TCA, the supernatants contained the acid - soluble phosphorous was discarded (19). For lipid extraction, the residue after removal of the acid soluble components was extracted 3 times with a mixture of coloroform: methanol (2: 1, V/V) (20). Testicular FFA was carried out according to the method of Farag et al. (21).

\section{3-Quantification of DNA Damage:}

High quality genomic DNA was extracted from the preserved testis by phenol/chloroform-based method through precipitation of protein and other contaminants and further precipitation of 
high molecular weight genomic DNA by absolute ethanol as described by Sambrook et al.(22).

\section{4-Determination of Biomarkers of Oxidative Stress:-}

Testicular homogenate level of malondialdehyde was performed according to hkawa et al., (23).

-Catalase activity was measured in testicular homogenate according to Aebi

-The activity of testicular Superoxide Dismutase(SOD) was determined according to Nishikimi et al. (26).

-Glutathione peroxidase activity (GPX) was measured by Paglia and Valentine's method (27).

-Glutathione reductase (GR) was detected by Bompart et al. (28)

\section{5- Histology:}

Four micron cryostal section of rat testis was prepared and fixed on histological slides and stained with Mayer's eosin and haematoxylin (29).

\section{Results:1- ecstacy administration altered polyunsaturated fatty acid composition in Testes:}

The testicular Linoleic Acid (LA) and Arachidonic Acid (AA) levels between ecstacy treated and non-treated groups are shown in table 1,2. We found that, only $30 \mathrm{mg} / \mathrm{kg} / \mathrm{d}$ ecstacy significantly decreased testicular LA $(\mathrm{p}<0.01-0.001)($ table 1,2$)$, while AA was contrary $(p<0.05$ $0.001)$ (table1, 2). Since LA is a precursor to $\mathrm{AA}$, these changes suggested enhanced conversion of LA to AA in testes .

\section{Results:2- ecstacy administration altered} oxidant/antioxidant composition in Testes:

Treatment with ecstacy $(10,30 \mathrm{mg} / \mathrm{kg})$ markedly destroyed the antioxidant system of the testes (table 3,4). Administration of ecstacy $(10,30 \mathrm{mg} / \mathrm{Kg})$ significantly elevated testis MDA level $(\mathrm{p}<0.001)$ while the activities of SOD,catalase, GR and GSH-Px were significantly reduced $(P<0.05-0.001)$ .The activities of SOD and GSH-Px were significantly reduced in rats treated with ecstacy $(P<0.05)$; however, there was a tendency for withdrawal with $10 \mathrm{mg}$ ecstacy to enhance the activities of enzymes and MDA level $(P<0.01)$.

Results 3:-DNA Fragmentation Assay: DNA fragmentation was examined by agarose gel electrophoresis. The results are represented in (fig1).. There are dose dependant DNA damage expressed as (1+), $(2+)$ and $(3+)$ for ecstacy groups as indicated in figure (1)Administration of ecstacy (30 $\mathbf{~} \mathbf{~ g / K g}$ ) for (15 days) caused DNA fragmentation in rat testis cells with $\mathbf{3}$ main fractions of fragments in diapasons 6055.61 b.p.; 4290.2 b.p.and3333.25b.p and one minor fraction from 2800 3200b.p.(+1),while administration of $(\mathbf{3 0}$ $\mathbf{m g} / \mathbf{K g}$ ) ecstacy for(30 days) caused DNA fragmentation in rat testis cells with $\mathbf{4}$ main fractions of fragments in diapasons 6156.55 b.p,5210.5 b.p,4955.21b.p.and 3400 b.p and 2 minor fraction at 2700-3200 b.p. and 1600-2600 b.p.(+2). On the other hand, administration of $(\mathbf{3 0} \mathrm{mg} / \mathbf{K g})$ ecstacy for $(\mathbf{4 5}$ days) caused DNA fragmentation in rat testis cells with $\mathbf{4}$ main fractions of fragments in diapasons 5908.33 b.p,4501.61 b.p,3621.27b.p.and 3200 b.p and 3 minor molecular weight fraction with DNA fragments 200-800 b.p. ,1500-2400 b.p. and1500-2400b.p. Withdrawal group caused DNA fragmentation in rat testis cells with 2 main fractions of fragments in diapasons 6029.2 and5651.25 b.p. and 3 minor fractions of DNA fragments 4001200; 1400-2500b.p.and 2600-3400 b.p. (+2) Only one fractions of DNA fragments: main-6151.33 b.p., and one minor-200-2800 b.p. were detected in the control group.

\section{Histological effects of ecstasy:}

Control rats showed normal testicular architecture with an orderly arrangement of germinal and Sertoli cells. Ecstasy treatment induced moderate to severe testicular atrophy with degeneration of germ cells in seminiferous tubules (Figure 2). The tubules were shrunken and greatly depleted of germ cells. There were depleted numbers of Leydig cells between the tubules. Sertoli cells with few germ cells were observed in the lumen. Animals treated with $10 \mathrm{mg}$ ecstasy showed normal testicular morphology with irregular arrangement of germ cells and slight degeneration of seminiferous epithelium and shedding of germ cells in some tubules.

\section{DISCUSSION:}

Ecstacy administration caused the production of oxygen active forms, activation of lipid peroxidation and oxidative stress development. Several 
reports indicate that reactive quinone metabolites of MDMA contribute to MDMA-mediated toxicities $(29 ; 30)$. Oxidative stress, in turn, can damage all intracellular macromolecules (glutathione, DNA, RNA, proteins, lipids and ATP). Any changes in the level of these substances are of key importance for cell viability and great deviations cause cell damage and death $(31,32)$.

Reactive oxygen species (ROS) play a central role for tests physiology, such as sperm maturation and capacity. On the other hand, abnormal ROS production is associated with defective testes function. The delicate balance between ROS production and recycling is essential for spermatogenesis. Excessive generation of seminal ROS can cause male infertility (33). Moreover, according to data of some authors( 34). ROS levels may be used as an early indicator of future sperm count and quality decline as a result of chronic toxic action of xenobiotics.

Lipids play a critical role in membrane structure and function, energy storage and cell signaling (35) . LA(18:2 n-6: the major PUFA in vegetable oils and is a metabolic precursor to AA (20:4 n-6) plays an important role in testicular function (36). The testicular LA and AA levels between ecstacy treated and non-treated groups are shown in table $(1,2)$. We found that , only $30 \mathrm{mg} / \mathrm{kg} / \mathrm{d}$ ecstacy recorded highly significantly decreased testicular LA $(\mathrm{p}<0.01-0.001)($ table1, 2), while AA was significantly elevated ( $p \quad<0.05-0.001)$ (table1, 2). Since LA is a precursor to AA, these changes suggested enhanced conversion of LA to AA in testes.

Decreased levels of LA and increased levels of AA were found in ecstacy exposed group. Because this kind of varied fatty acid composition might biologically adapt to oxidative stress $(37,38)$ we predicted that oxidative stress occurred in the testes.

Treatment with ecstacy $(10,30 \quad \mathrm{mg} / \mathrm{kg})$ markedly destroyed the antioxidant system of the testes (table 3,4). Administration of ecstacy $(10,30 \mathrm{mg} / \mathrm{Kg})$ significantly elevated testis MDA level $(\mathrm{p}<0.001)$ while the activities of SOD, catalase, GR and GSHPx were significantly decreased $(P<0.05$ -
0.001) .The activities of SOD and GSH-Px were significantly reduced in rats treated with ecstacy $(P<0.05)$; however, there was a tendency for withdrawal with $10 \mathrm{mg}$ ecstacy to enhance the activities of enzymes and MDA level $(P<0.01)$.

Oxidant/antioxidant imbalance in the testes may induce oxidative stress and thereby hamper testicular function (39). The current study confirmed that lipid peroxidation, a downstream chain reaction initiated by free radicals, was activated by ecstacy as reflected by the increased level of lipoperoxidation product, MDA, in testes, demonstrating the extraordinary sensitivity of this tissue to free radical injury by this exogenous, pro-oxidative agent, ecstacy. This phenomenon could be at least partially attributable to the structure of the male germ cell membrane, which is rich in polyunsaturated fatty acids and is thereby particularly prone to lipid peroxidation (40).Moreover, our findings also demonstrated that the crucial endogenous antioxidant enzymes (SOD, CaT, GR GPx), responsible for scavenging superoxide radicals were markedly suppressed by ecstacy, which might cause excessive consumption, reduced production, or chemical deactivation of these enzymes ( 41). Testicular oxidative stress induced by ecstacy administration was also reported in a recent published report by Byoung et al. (42). Lipid peroxidation can profoundly affect sperm quality, including the percentage of motility and specific motility parameters (43)

Oxidative stress could cause both membrane lipid peroxidation and DNA fragmentation in testes ( 36). It is reported that spermatogenesis and Leydig cell steroidogenisis are both vulnerable to oxidative stress. (44) . Microscopically, the lesions in the testes of ecstacy intoxicated rats at $45^{\text {th }}$ day revealed destruction of seminiferous tubules at periphery. No spermatid and spermatocytes were seen in the seminiferous tubules. Detachment of spermatogonial cells started at periphery of seminiferous tubules. Atrophy of seminiferous tubules was a constant finding. Some tubules showed vacuolar degenerative changes in germinal 
epithelium. During the recovery period, destruction of seminiferous tubules, detachment of spermatogonial cells, and atrophy of seminiferous tubules were observed in group $\mathrm{F}$ andG. A plausible explanation of decreased spermatogenesis of the rat model in present study is oxidant/antioxidant imbalance, which is widely supported by population and animal studies, (45).

Clinical studies have demonstrated that male infertility patients showed higher oxidative stress and related decreased SOD and GSH-Px levels (46). Additionally, oxidative stress and disturbed equilibrium of oxidant/antioxidant has been suggested as a major mechanism of reproductive toxicity (47). The rate and character of DNA-fragmentation is a marker of apoptotic processes in the organism (48). Genomic DNA constitutes the total genetic information of an organism. The genomes of almost all organisms are DNA, the only exceptions being some viruses that have RNA genomes. Genomic DNA molecules are generally large and in most organisms are organized into DNA-protein complexes called chromosomes. The size, number of chromosomes and nature of genomic DNA varies between different organisms.

In the present study, toxic damage of testis cells by administration of ecstacy drugs (confirmed by histological data was accompanied by changes of nuclear DNA fragmentation (Figure 1).

DNA fragmentation was examined by agarose gel electrophoresis. The results are represented in (fig1), indicating random DNA fragmentation, a hallmark of necrosis. There are dose dependant DNA damage expressed as (1+), (2+) and (3+) for ecstacy groups as indicated in figure 1 . Administration of ecstacy ( $30 \mathrm{mg} / \mathrm{Kg}$ ) for (15 days) caused DNA fragmentation in rat testis cells with $\mathbf{3}$ main fractions of fragments in diapasons 6055.61 b.p.; 4290.2 b.p.and3333.25b.p and one minor fraction from $2800-3200$ b.p.(+1), while administration of $(30 \quad \mathrm{mg} / \mathrm{Kg})$ ecstacy for(30 days) caused DNA fragmentation in rat testis cells with 4 main fractions of fragments in diapasons 6156.55 b.p, 5210.5 b.p,4955.21b.p.and 3400 b.p and 2 minor fraction at 2700-3200 b.p. and 1600-2600 b.p. $(+2)$. On the other hand, administration of $(30 \mathrm{mg} / \mathrm{Kg})$ ecstacy for(45 days) caused DNA fragmentation in rat testis cells with 4 main fractions of fragments in diapasons 5908.33 b.p, 4501.61 b.p,3621.27b.p.and 3200 b.p and 3 minor molecular weight fraction with DNA fragments $200-800$ b.p. ,1500-2400 b.p. and1500-2400b.p. Withdrawal group caused DNA fragmentation in rat testis cells with 2 main fractions of fragments in diapasons 6029.2and5651.25 b.p. and $\mathbf{3}$ minor fractions of DNA fragments 400-1200; 1400-2500b.p.and 2600-3400 b.p. (+2) Only one fractions of DNA fragments: main-6151.33 b.p., and one minor-2002800 b.p. were detected in the control group.

Differences in DNA fragmentation in experimental and control groups may be caused by activation of different sets of nucleases (49) and different rates of lipid peroxidation (50). Depending on the quality and quantity of nucleases, the levels of DNA oxidative damage DNA fragmentation results in high or low molecular weight fractions only or in high and lower molecular weight fractions simultaneously (51). Many of the reproductive toxic agents studied exhibit cell-type specificity resulting in increased DNA fragmentation in testis. (52;53) There are various mechanisms that result in DNA strand breaks in testis. One of the primary DNA damaging agents receiving a lot of research attention is reactive oxygen species (ROS) (35). This toxic potential is mainly due to adduct formation with DNA, RNA and protein. The adduct formation (DNA Fragmentation) in the tissue cells which derives from covalent bond formation between epoxides and $\mathrm{N}$ of guanine bases in DNA (42).

Histological examination of testis tissue in ecstacy treated male rats significantly revealed marked changes included moderate to severe testicular atrophy with degeneration of germ cells in seminiferous tubules (Figure 2). The tubules were shrunken and greatly depleted of germ 
cells. There were depleted numbers of Leydig cells between the tubules. Sertoli cells with few germ cells were observed in the lumen. Animals treated with $10 \mathrm{mg}$ ecstasy showed normal testicular morphology with irregular arrangement of germ cells and slight degeneration of seminiferous epithelium and shedding of germ cells in some tubules. These changes can be explained by Altavilla et al.,(54)who stated that mitochondria are the critical targets for drug toxicity, either directly or indirectly through the formation of reactive metabolites. The consequence of these modifications is generally a mitochondrial oxidant stress and nitrophil formation, which leads to structural alterations of proteins and mitochondrial DNA and, eventually, to the opening of mitochondrial membrane permeability transition (MPT) pores. MPT pore formation results in a collapse of mitochondrial membrane potential and cessation of adenosine triphosphate synthesis. In addition, the release of intermembrane proteins, such as apoptosis-inducing factor and endonuclease $\mathrm{G}$, and their translocation to the nucleus, leads to nuclear DNA fragmentation. Together, these events trigger necrotic cell death.

\section{In conclusion:}

this study provides evidence that ecstacy adversely damages testicular tissue and significantly reduces sperm production through increasing oxidative stress and inducing apoptosis. This review of the literature indicates that ecstasy (MDMA) and related drugs are potentially dangerous, even in the doses typically used by participants at raves. The chronic effects can lead to serious and even fatal toxicity, the full extent of which cannot yet be estimated with accuracy. The variety of different adverse effects, including psychiatric, neurological, cardiovascular, hepatic, renal, thermoregulatory and even dental problems, indicates that patients with ecstasy-related difficulties may present in any part of the health care system and not only to emergency services. Because the main users are adolescents and young adults following the dictates of current drug fashion, physicians may need to be especially alert to such problems in an otherwise healthy population group. The results suggested additive interactions on the deleterious effects of ecstacy on the histological structure of the reproductive system in male rats. The data presented showed that ecstacy at graded doses induced severe oxidative damage in the testis and accessories promoting their apoptosis and thus consuming such doses simultaneously may be a greater risk of male infertility.

\section{References:}

1-Capela JP, Carmo H, Remião F, Bastos ML, Meisel A, Carvalho F. ,(2009) :Molecular and cellular mechanisms of ecstasy-induced neurotoxicity: an overview. Mol Neurobiol .,39:210-271.

2-Substance Abuse and Mental Health Services Administration, (2010)

3-Schulz S, Becker T, Nagel U, von AmelnMayerhofer A, Koch M.,(2013): Chronic co-administration of the cannabinoid receptor agonist WIN55,212-2 during puberty or adulthood reverses 3,4 methylenedioxymetamphetamine (MDMA)induced deficits in recognition memory but not in effort-based decision making. Pharmacol Biochem Behav.,doi:pii: S00913057(13)00077-4.

10.1016/j.pbb.2013.03.011. [Epub ahead of print]

4-Rouine J, Gobbo OL, Campbell M, Gigliucci V, Ogden I, McHugh Smith K, Duffy P, Behan B, Byrne D, Kelly ME, Blau CW, Kerskens CM, Harkin A.,2013: MDMA "Ecstasy" increases cerebral cortical perfusion determined by bolus-tracking arterial spin labelling (btASL) MRI. Br J Pharmacol. ,doi: 10.1111/bph.12178. [Epub ahead of print].

5-Nelson AJ, Thur KE, Marsden CA, Cassaday HJ.,2013: Paradoxical effects of low dose MDMA on latent inhibition in the rat. Neuropharmacology.;67:331-6.

6-Peiró AM, Farré M, Roset PN, Carbó M, Pujadas M, Torrens M, Camí J, de la Torre R.,2013: Human pharmacology of 3,4methylenedioxymethamphetamine (MDMA, ecstasy) after repeated doses taken $2 \mathrm{~h}$ apart. Psychopharmacology ,225(4):883-93.

7-Mueller M, Maldonado-Adrian C, Yuan J, McCann UD, Ricaurte GA.,2013: Studies of ( \pm )3,4-methylenedioxymethamphetamine (MDMA) metabolism and disposition in rats and mice: relationship to neuroprotection and neurotoxicity profile. J Pharmacol Exp Ther.,344(2):479-88. 
8-Flavel SC, Koch JD, White JM, Todd G.,2012: Illicit stimulant use in humans is a ssociated with a long-term increase in tremor. PLoS One,7(12):e52025.

9-Todd G, Noyes C, Flavel SC, Della Vedova CB, Spyropoulos P, Chatterton B, Berg D, White JM.,2013: Illicit stimulant use is associated with abnormal substantia nigra morphology in humans. PLoS One.,8(2):e56438.

10-Daveluy A, Miremont-Salamé G, Kostrzewa A, Couret A, Lacoin L, Lecomte C, Moore N, Gilleron V, Haramburu F.,2012: Identification of abuse and dependence cases through a hospital database. Pharmacoepidemiol Drug Saf.,21(12):1344-9.

11-Ghandour LA, El Sayed DS, Martins SS.,2013: Alcohol and Illegal Drug Use Behaviors and Prescription Opioids Use: How Do Nonmedical and Medical Users Compare, and Does Motive to Use Really Matter?. Eur Addict Res.,19(4):202-210.

12-Scott RM, Hides L, Allen JS, Lubman DI.,2013: Subacute effects of ecstasy on mood: an exploration of associated risk factors. J Psychopharmacol.;27(1):53-61.

13-Capela JP, da Costa Araújo S, Costa VM, Ruscher K, Fernandes E, Bastos Mde L, Dirnagl U, Meisel A, Carvalho F.,2013: The neurotoxicity of hallucinogenic amphetamines in primary cultures of hippocampal neurons. Neurotoxicology.,34:254-63.

14-Barenys $M$, Macia $N$, Camps $L$, de Lapuente J, Gomez-Catalan J, GonzalezLinares J, Borras M, Rodamilans M, Llobet JM.,2009: Chronic exposure to MDMA (ecstasy) increases DNA damage in sperm and alters testes histopathology in male rats. Toxicol Lett.,191(1):40-6.

15-Barenys M, Gomez-Catalan J, Camps L, Teixido E, de Lapuente J, 2010: MDMA (ecstasy) delays pubertal development and alters sperm quality after developmental exposure in the rat. Toxicol Lett.,197(2):135-42.

16-Milroy CM and Parai JL.,2011: The histopathology of drugs of abuse. Histopathology,59(4):579-93.

17- Lewi Paul $\mathbf{J}$ and Marsboom, Robert P.,(1981): Toxicology, Experimental; Rats as laboratory animals; Data collection; Toxicology; Tables. Elsevier/North-Holland Biomedical Press, Amsterdam (ed.):3.

18-Paget GE and Barnes JM., (1964): Evaluation of drug activities and phamacometries. Editors: RR Laurence and Bacharach AL, Academic Press, London,(1),pp.135-166.

19-Schneider, W.C.; Hogeboom, G.N. and Ross, H.E.,1950: Extraction of Nucleic Acids in Biological Fluids, Journal of the National Cancer Institute, (10), p. 977.
20-Bligh, E.G. and Dyer, W.J.,1959: Total Lipid Extraction and Purification, Canadian Journal of Biochemical Physiology, 37: 911.

21-Farag, R.S.; Hallabo, S.A.; Hewid, F.M. and Basyony, A.E.,1986: Chemical Evaluation of Rapeseed, Fette-Seifen Anstrichmittel, 88 (10), p. 39.

22-Sambrook, J., E. Fritsch and T. Maniutis,1989:Molecular cloning A laboratory manual 2nd Ed. Cold Spring Harbor Laboratory Press USA, aflatoxin on red blood corpuscles. Bull. Environ.pp: 6366.

23-Hkawa, $\mathrm{H}$; Ohishi,N and Yagi, k., 1979. Assay for peroxides in animal tissues by thiobarbituric acid. Anal. Biochem., 95: 351-358.

24-Aebi, H., 1984. Catalase in vitro . Methods Enzymol., 108: 121-126.

25-Nishikimi, M.; Roa, NA and Yogi, K. 1972: Measurement of superoxide dismutase. Biochem. Bioph. Res. Common., 46: 849-854.

26-Paglia DE and Valentine WN.,(1967): Studies on the quantitative and qualitative characterization of erythrocyte glutathione peroxidase. J Lab Clin Med.,70:158-169.

27--Bompart GJ ; Prévot DS and Bascands JL.,(1990): Rapid automated analysis of glutathione reductase, peroxidase, and Stransferase activity: application to cisplatininduced toxicity. Clin Biochem., 23(6): 501504.

28-Humason GL., (1972): Preparation and staining of histological specimen. In: "Animal tissue techniques" $3^{\text {rd }}$ ed., W.H. Freeman and Co., Sanfrancisco.

29-Reha Celikel, Eric C Peterson, S Michael Owens, Kottayil I Varughese.,2009: Crystal structures of a therapeutic single chain antibody in complex with two drugs of abuse-Methamphetamine and 3,4-methylenedioxymethamphetamine. Protein Sci., 18(11): 2336-2345.

30--Katherine Esse, Marco Fossati-Bellani, Angela Traylor, Sheryl MartinSchild.,2011: Epidemic of illicit drug use, mechanisms of action/addiction and stroke as a health hazard. Brain Behav.; 1(1): 44-54.

31-Cooke MS, Evans DM, Dizdaroglu M, Lunec J.,2003: Oxidative DNA damage: mechanisms, mutation, and disease. The FASEB Journal.,17:1195-1214.

32-Jones DP.,2008: Radical-free biology of oxidative stress. Am J Physiol Cell Physiol.,295:C849-C868.

33-Hsien YY, Chang CC, Lin CS. ,2006:Seminal malondialdehyde concentration but not glutathione peroxidase activity is negatively correlated with seminal 
concentration and motility. Int $\mathrm{J}$ Biol Sci.,2(1):23-9.

34-Minamiyama Y, Ichikava $H$, Takemura S, et al.,2010: Generation of reactive oxygen species in sperms of rats as an earlier marker for evaluating the toxicity of endocrinedisrupting chemicals. Free Radic Res.,44(12):1398-1406.

35-Oresic M, Hänninen VA, Vidal-Puig A., (2008) :Lipidomics: a new window to biomedical frontiers. Trends Biotechnol .,26: 647-652.

36-Ahmed, K A, M.M. El Mahady MM, Badawy SA, Ahmed YF and Aly MA.,2012: Pathological Consequences of Aflatoxins in Male Rabbit: Cellular, Genetic and Oxidative Damage. Global Veterinaria 9 (1): 42-52.

37- Aitken RJ and Roman SD.,2008: Antioxidant systems and oxidative stress in the testes. Oxid Med Cell Longev., 1(1): 1524.

38-Patra ,RC; Rautray ,AK and Swarup,D.,2011: Lead and Cadmium Toxicity and Its Amelioration. Veterinary Medicine International,V. (2011), Article ID 457327, 9 pages.

39-Saradha B, Mathur PP (2006): Effect of environmental contaminants on male reproduction. Environ Toxicol Pharmacol., 21: 34-41.

40-Lenzi A, Gandini L, Lombardo F, Picardo M, Maresca V, Panfili E, et al.,2002: Polyunsaturated fatty acids of germ cell membranes, glutathione and blutathionedependent enzyme-PHGPx: from basic to clinic. Contraception, 65:301-304.

41-Mohan IK, Kumar KV, Naidu MU, Khan M, Sundaram C.,2006: Protective effect of CardiPro against doxorubicininduced cardiotoxicity in mice. Phytomedicine, 13:222-229.

42-Byoung-Joon Song; Kwan-Hoon Moon; Vijay V. Upreti; Natalie D. Eddington; andInsong J. Lee.,2010: Mechanisms of MDMA (Ecstasy)-Induced Oxidative Stress, Mitochondrial Dysfunction, and Organ Damage.Curr Pharm Biotechnol., 11(5): 434-443.

43-Bansal AK, Bilaspuri GS.,2011: Impacts of oxidative stress and antioxidants on semen functions. Vet Med Int., 7:1-7 .

44-Appasamy M, Muttukrishna S, Pizzey AR, Ozturk O, Groome NP, et al. (2007): Relationship between male reproductive hormones, sperm DNA damage and markers of oxidative stress in infertility. Reprod Biomed .,14: 159-165.
45-Aly HA, Domènech O, Abdel-Naim AB (2009): Aroclor 1254 impairs spermatogenesis and induces oxidative stress in rat testicular mitochondria. Food Chem Toxicol., 47: 1733-1738.

46Dandekar SP, Nadkarni GD, Kulkarni VS, Punekar S (2002) :Lipid peroxidation and antioxidant enzymes in male infertility. J Postgrad Med., 48: 186-189.

47-Mathur PP, D'Cruz SC (2011): The effect of environmental contaminants on testicular function. Asian J Androl .,13: 585591.

48-Wang $X$ and Lu Y.,2005: Cederbaum AI. Induction of cytochrome P450 2E1 increases hepatotoxicity caused by Fas agonistic Jo2 antibody in mice. Hepatology.,42:400-410.

49-Ganna Mykhailivna Shayakhmetova, Larysa Borysivna Bondarenko, and Valentina Mykolaivna Kovalenko.,2012: Damage of testicular cell macromolecules and reproductive capacity of male rats following co-administration of ethambutol, rifampicin, isoniazid and pyrazinamide. Interdiscip Toxicol., 5(1): 9-14.

50-Aitken RJ, Koppers AJ.,2011: Apoptosis and DNA damage in human spermatozoa. Asian Androl.,13(1):36-42.

51-Nizar Abd Manan;Norazlina Mohamed and Ahmad Nazrun Shuid.,2012: Effects of Low-Dose versus High-Dose $\gamma$-Tocotrienol on the Bone Cells Exposed to the Hydrogen Peroxide-Induced Oxidative Stress and Apoptosis .Evidence-Based Complementary and Alternative Medicine,Volume (2012), 10 pages.

52-Shayakhmetova GM, Bondarenko LB, Kovalenko VM.,2012: Damage of testicular cell macromolecules and reproductive capacity of male rats following coadministration of ethambutol, rifampicin, isoniazid and pyrazinamide. Interdiscip Toxicol.,5(1):9-14.

53-Celik O, Kutlu O, Tekcan M, CelikOzenci C, T Koksal I.,2013: Role of TNFrelated apoptosis-inducing ligand (TRAIL) in the pathogenesis of varicocele-induced testicular dysfunction. Asian J Androl.,15(2):269-74.

54-Altavilla D, Romeo C, Squadrito F, Marini H, Morgia G, Antonuccio P, Minutoli L.,2012: Molecular pathways involved in the early and late damage induced by testis ischemia: evidence for a rational pharmacological modulation. Curr Med Chem.,19(8):1219-24. Review. 
Table(1):Effect of chronic administration of ecstasy $(10 \mathrm{mg} / \mathrm{kg})$ on testes free fatty acids of Male Rats.

\begin{tabular}{|c|c|c|c|c|c|c|}
\hline \begin{tabular}{|l|} 
Free fatty \\
acids $\mu \mathrm{g} / \mathrm{g}$
\end{tabular} & $\begin{array}{l}\text { Chemical } \\
\text { formula }\end{array}$ & $\begin{array}{l}\text { Retention } \\
\text { time(min) }\end{array}$ & C & 15d & 30d & 45d \\
\hline $\begin{array}{ll}\text { LA } & \text { Mean } \\
\pm \text { S.D } & \end{array}$ & $\mathrm{C}_{18} \mathrm{H}_{32} \mathrm{O}_{2}$ & 17.783 & $\begin{array}{l}254.1 \pm 3 . \\
05\end{array}$ & $245.8 \pm 4.04$ & $227.1 \pm 3.11$ & $251.3 \pm 2.05$ \\
\hline \% change & & & & -3.266 & -10.626 & -1.10 \\
\hline $\mathbf{P}<$ & & & & N.S. & N.S. & N.S. \\
\hline $\begin{array}{l}\text { AA(Mean } \\
\text { +S.D } \\
\end{array}$ & $\mathrm{C}_{20} \mathrm{H}_{32} \mathrm{O}_{2}$ & 24.650 & $344.8 \pm 5.07$ & $359.7 \pm 3.02$ & $394.0 \pm 4.06$ & $400.5 \pm 5.091$ \\
\hline \% change & & & & 4.32 & 14.27 & 16.154 \\
\hline $\mathbf{P}<$ & & & & N.S. & 0.05 & 0.05 \\
\hline
\end{tabular}

LA: Linoleic Acid (18:2 n-6),AA: Arachidonic Acid (20:4 n-6) P-value $<0.05$ statistically significant, $\mathrm{D}_{15}, \mathrm{D}_{30}, \mathrm{D}_{45}=$ duration of time taken $15,30,45$ days.

Table( 2):Effect of chronic administration of ecstasy $(30 \mathrm{mg} / \mathrm{kg})$ on testes free fatty acids of Male Rats.

\begin{tabular}{|c|c|c|c|c|c|c|}
\hline \begin{tabular}{|l} 
Free fatty \\
acids $\mu \mathrm{g} / \mathrm{g}$
\end{tabular} & $\begin{array}{l}\text { Chemical } \\
\text { formula }\end{array}$ & $\begin{array}{l}\text { Retention } \\
\text { time(min) }\end{array}$ & C & $15 d$ & 30d & 45d \\
\hline $\begin{array}{ll}\text { LA } & \text { Mean } \\
\pm & \end{array}$ & $\mathrm{C}_{18} \mathrm{H}_{32} \mathrm{O}_{2}$ & 17.783 & $\begin{array}{l}254.1 \pm 3 . \\
05\end{array}$ & $185.8 \pm 4.04$ & $167.1 \pm 6.11$ & $151.3 \pm 7.05$ \\
\hline \% change & & & & -26.88 & -34.24 & -40.457 \\
\hline $\mathbf{P}<$ & & & & 0.01 & 0.001 & 0.001 \\
\hline $\begin{array}{l}\text { AAMean } \\
\text { +S.D }\end{array}$ & $\mathrm{C}_{20} \mathrm{H}_{32} \mathrm{O}_{2}$ & 24.650 & $344.8 \pm 5.07$ & $459.7 \pm 4.02$ & $494.0 \pm 4.06$ & $500.5 \pm 5.091$ \\
\hline \% change & & & & 33.32 & 43.27 & 45.16 \\
\hline 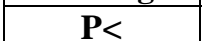 & & & & 0.001 & 0.001 & 0.001 \\
\hline
\end{tabular}

LA: Linoleic Acid (18:2 n-6),AA: Arachidonic Acid (20:4 n-6) P-value <0.05 statistically significant, $\mathrm{D}_{15}, \mathrm{D}_{30}, \mathrm{D}_{45}=$ duration of time taken $15,30,45$ days.

Table (3): Effect of chronic administration of $10 \mathrm{mg} / \mathrm{kg}$ BW/day MDMA (ecstasy)on testis oxidant / antioxidant status in Rats.

\begin{tabular}{|c|c|c|c|c|c|c|}
\hline \multicolumn{2}{|c|}{$\begin{array}{l}\text { Parameter } \\
\text { Groups }\end{array}$} & $\begin{array}{l}\text { MDA } \\
\mathbf{m m o l} / \mathbf{1 0 m g}\end{array}$ & $\begin{array}{l}\text { SOD } \\
\text { U/10mg }\end{array}$ & $\begin{array}{l}\text { CAT } \\
\text { U/10mg }\end{array}$ & $\begin{array}{l}\text { GPX } \\
\text { U/10mg }\end{array}$ & $\begin{array}{l}\text { GR } \\
\text { U/10mg }\end{array}$ \\
\hline Cont & $\begin{array}{l}\text { Range } \\
\text { Mean } \pm \text { SD }\end{array}$ & $\begin{array}{l}\text { (3.61-4.35) } \\
3.19 \pm 0.34\end{array}$ & $\begin{array}{l}\text { (28.65-39.41) } \\
33.17 \pm 3.46\end{array}$ & $\begin{array}{l}(7.92-11.36) \\
9.13 \pm 1.17\end{array}$ & $\begin{array}{l}(17.95-18.74) \\
18.01 \pm 2.11\end{array}$ & $\begin{array}{l}(6.71-8.87) \\
7.84 \pm 0.75\end{array}$ \\
\hline$D_{15}$ & $\begin{array}{l}\text { Range } \\
\text { Mean } \pm \text { SD } \\
\% \text { change } \\
\text { P< }\end{array}$ & $\begin{array}{l}(3.7-5.11) \\
3.76 \pm 0.31 \\
17.8 \\
0.001\end{array}$ & $\begin{array}{l}(23.11-44.193) \\
29.48 \pm 3.17 \\
-11.37 \\
\text { N.S. }\end{array}$ & $\begin{array}{l}(8.41-15.32) \\
8.98 \pm 2.74 \\
-1.64 \\
\text { N.S. }\end{array}$ & $\begin{array}{l}(16.481-19.91) \\
18.53 \pm 3.81 \\
+2.89 \\
\text { N.S. }\end{array}$ & $\begin{array}{l}(6.31-9.15) \\
7.51 \pm 0.45 \\
-4.21 \\
\text { N.S. }\end{array}$ \\
\hline $\mathbf{D}_{\mathbf{3 0}}$ & $\begin{array}{l}\text { Range } \\
\text { Mean } \pm \text { SD } \\
\% \text { change } \\
\text { P< }\end{array}$ & $\begin{array}{l}(4.32-5.61) \\
4.71 \pm 0.54 \\
47.65 \\
0.001\end{array}$ & $\begin{array}{l}(20.19-33.93) \\
26.4 \pm 4.12 \\
-14.79 \\
0.05\end{array}$ & $\begin{array}{l}\text { (7.81-8.91) } \\
8.01 \pm 2.81 \\
-12.27 \\
0.05\end{array}$ & $\begin{array}{l}(15.93-18.31) \\
16.91 \pm 2.15 \\
-6.11 \\
\text { N.S. }\end{array}$ & $\begin{array}{l}(5.93-7.69) \\
7.21 \pm 0.93 \\
-8.04 \\
0.05\end{array}$ \\
\hline $\mathbf{D}_{45}$ & $\begin{array}{l}\text { Range } \\
\text { Mean } \pm \text { SD } \\
\% \text { change } \\
\text { P< }\end{array}$ & $\begin{array}{l}(3.91-5.93) \\
5.79 \pm 0.149 \\
81.51 \\
0.001\end{array}$ & $\begin{array}{l}(16.01-33.93) \\
21.08 \pm 3.75 \\
-36.45 \\
0.01\end{array}$ & $\begin{array}{l}(6.91-7.64) \\
7.78 \pm 2.15 \\
-14.79 \\
0.025\end{array}$ & $\begin{array}{l}(14.83-16.18) \\
16.12 \pm 1.81 \\
-10.50 \\
0.05\end{array}$ & $\begin{array}{l}(5.31-7.78) \\
7.08 \pm 0.74 \\
-9.69 \\
0.05\end{array}$ \\
\hline $\mathrm{W}_{15}$ & $\begin{array}{l}\text { Range } \\
\text { Mean } \pm \text { SD } \\
\% \text { change } \\
\text { P< }\end{array}$ & $\begin{array}{l}(3.24-4.59) \\
3.79 \pm 0.94 \\
18.81 \\
0.01\end{array}$ & $\begin{array}{l}(26.13-34.15) \\
29.13 \pm 2.84 \\
-12.27 \\
0.05\end{array}$ & $\begin{array}{l}(8.1-10.31) \\
8.34 \pm 2.17 \\
8.65 \\
\text { N.S. }\end{array}$ & $\begin{array}{l}(17.34-19.12) \\
17.04 \pm 3.19 \\
-5.61 \\
\text { N.S. }\end{array}$ & $\begin{array}{l}(5.84-8.31) \\
7.39 \pm 3.81 \\
-5.74 \\
\text { N.S. }\end{array}$ \\
\hline
\end{tabular}

P-value $<0.05$ statistically significant, $\mathrm{D}_{15}, \mathrm{D}_{30}, \mathrm{D}_{45}$ and $\mathrm{W}_{15}=$ duration of time taken $15,30,45$ and with 15 days. 
Table (4): Effect of chronic administration of $30 \mathrm{mg} / \mathrm{kg}$ BW/day MDMA (ecstasy)on testis oxidant / antioxidant status in Rats.

\begin{tabular}{|c|c|c|c|c|c|c|}
\hline \multicolumn{2}{|c|}{$\begin{array}{l}\text { Parameter } \\
\text { Groups }\end{array}$} & $\begin{array}{l}\text { MDA } \\
\text { mmol/10mg }\end{array}$ & $\begin{array}{l}\text { SOD } \\
\text { U/10mg } \\
\end{array}$ & $\begin{array}{l}\text { CAT } \\
\text { U/10mg } \\
\end{array}$ & $\begin{array}{l}\text { GPX } \\
\text { U/10mg } \\
\end{array}$ & $\begin{array}{l}\text { GR } \\
\text { U/10mg } \\
\end{array}$ \\
\hline Cont & $\begin{array}{l}\text { Range } \\
\text { Mean } \quad \pm \\
\text { SD }\end{array}$ & $\begin{array}{l}(3.61-4.35) \\
3.19 \pm 0.34\end{array}$ & $\begin{array}{l}(28.65- \\
39.41) \\
33.17 \pm 3.46\end{array}$ & $\begin{array}{l}7 . \quad 92-11 . \\
36) \\
9.13 \pm 1.17\end{array}$ & $\begin{array}{l}(17.95- \\
18.74) \\
18.01 \pm 2.11\end{array}$ & $\begin{array}{l}(6.71-8.87) \\
7.84 \pm 0.75\end{array}$ \\
\hline$D_{15}$ & $\begin{array}{l}\text { Range } \\
\text { Mean } \\
\pm \text { SD } \\
\% \text { change } \\
\text { P< } \\
\end{array}$ & $\begin{array}{l}(5.1-10.11) \\
4.81 \pm 1.31 \\
+50.784 \\
0.001\end{array}$ & $\begin{array}{l}(13 . \quad 11-24 . \\
93) \\
23.11 \pm 3.24 \\
-30.33 \\
0.001 .\end{array}$ & $\begin{array}{l}(6.41-10 . \\
32) \\
7.31 \pm 1.84 \\
-19.93 \\
0.01 \\
\end{array}$ & $\begin{array}{l}(9.01-18.61) \\
14.11 \pm 3.42 \\
-21.65 \\
0.01\end{array}$ & $\begin{array}{l}(5.31-8.05) \\
6.51 \pm 0.45 \\
-16.96 \\
0.001\end{array}$ \\
\hline $\mathbf{D}_{30}$ & $\begin{array}{l}\text { Range } \\
\text { Mean } \pm \\
\text { SD } \\
\% \text { change } \\
\mathrm{P}< \\
\end{array}$ & $\begin{array}{ll}(6.32 & - \\
11.67) \\
6.71 \pm 2.54 \\
+110.345 \\
0.001 \\
\end{array}$ & $\begin{array}{l}(16.91- \\
23.93) \\
20.23 \pm 3.19 \\
-39.011 \\
0.001\end{array}$ & $\begin{array}{l}(5.81-8.91) \\
6.61 \pm 1.81 \\
-27.60 \\
0.001\end{array}$ & $\begin{array}{l}(9.80-17.31) \\
13.15 \pm 2.65 \\
-26.99 \\
0.001\end{array}$ & $\begin{array}{l}(5.13-7.69) \\
5.84 \pm 0.93 \\
-25.5 \\
0.001\end{array}$ \\
\hline $\mathbf{D}_{45}$ & $\begin{array}{l}\text { Range } \\
\text { Mean } \pm \\
\text { SD } \\
\% \text { change } \\
\text { P< }\end{array}$ & $\begin{array}{l}5 . \quad 91-10 . \\
93) \\
7.29 \pm 2.149 \\
+128.53 \\
0.001\end{array}$ & $\begin{array}{l}(12.11-23 . \\
89) \\
16.54 \pm 3.75 \\
-50.14 \\
0.001\end{array}$ & $\begin{array}{l}(4.91-7.64) \\
5.77 \pm 2.15 \\
-36.80 \\
0.001\end{array}$ & $\begin{array}{l}(8.93-16.18) \\
12.02 \pm 2.53 \\
-33.26 \\
0.001\end{array}$ & $\begin{array}{l}(4.81-6.71) \\
5.13 \pm 0.74 \\
-34.57 \\
0.001\end{array}$ \\
\hline $\mathbf{W}_{15}$ & $\begin{array}{l}\text { Range } \\
\text { Mean } \pm \\
\text { SD } \\
\% \text { change } \\
\text { P< } \\
\end{array}$ & $\begin{array}{l}5.23-11 . \\
19) \\
6.79 \pm 1.64 \\
+112.85 \\
0.001\end{array}$ & $\begin{array}{l}(16 . \quad 13-24 . \\
65) \\
19.13 \pm 3.34 \\
-42.33 \\
0.001\end{array}$ & $\begin{array}{l}\text { (7.11-10.31) } \\
7.04 \pm 1.17 \\
-23.33 \\
0.001\end{array}$ & $\begin{array}{l}(10.38- \\
17.14) \\
14.86 \pm 3.18 \\
-17.49 \\
0.01 \\
\end{array}$ & $\begin{array}{l}(4.84-6.011) \\
5.69 \pm 1.41 \\
-27.42 \\
0.001\end{array}$ \\
\hline
\end{tabular}

P-value $<0.05$ statistically significant, $\mathrm{D}_{15}, \mathrm{D}_{30}, \mathrm{D}_{45}$ and $\mathrm{W}_{15}=$ duration of time taken $15,30,45$ and with 15 days. 


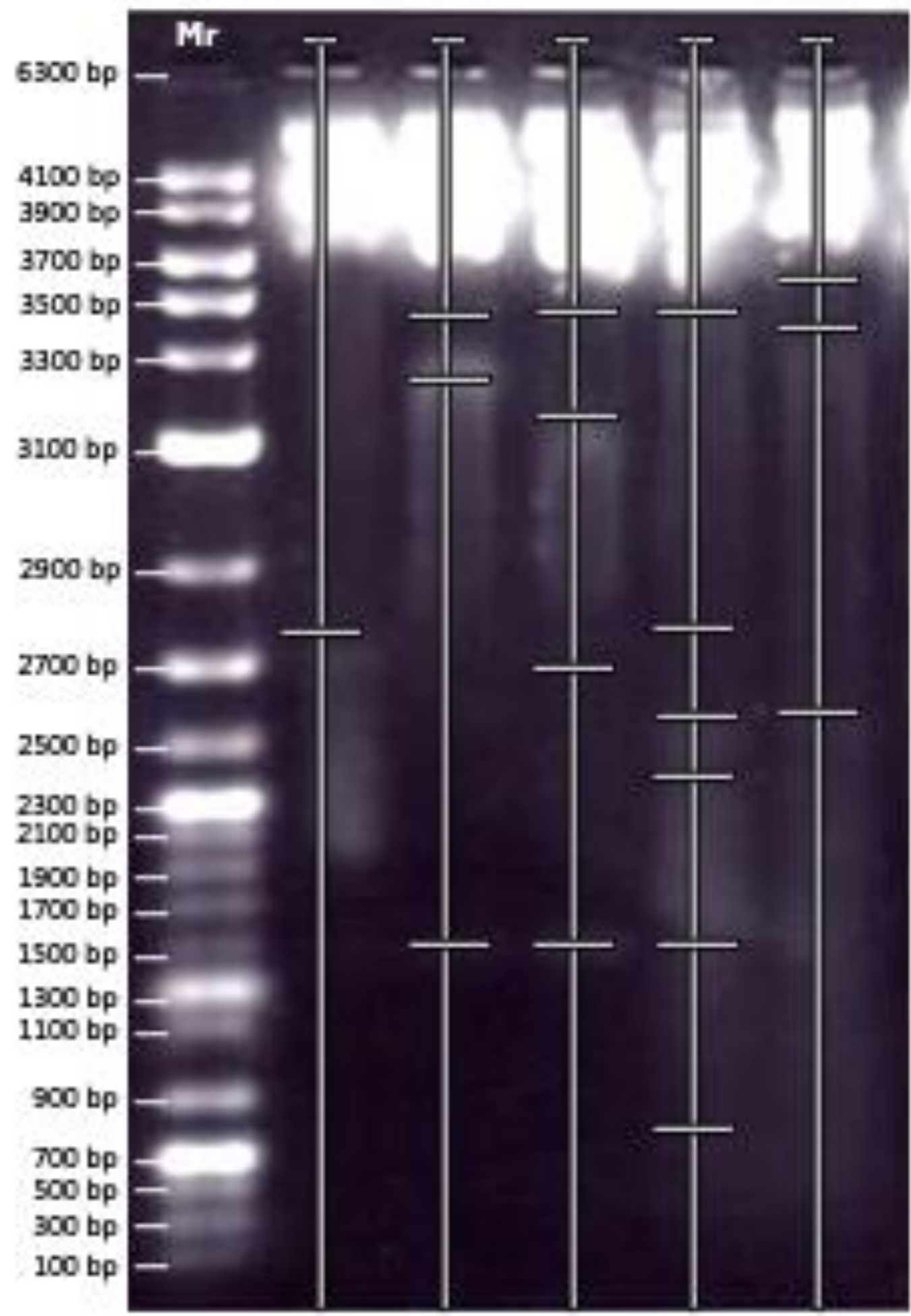

Fig 1: DNA fragmentation on agarose/ethidium bromide gel in testicular homogenate:Lane (1) Kbp DNA marker; Lane (2) control showed no degree of DNA fragmentation; Lane (3) showed (1+) DNA fragmentation in this group; Lane (4) showed (2+) DNA fragmentation in this group; Lane (5) showed (3+) DNA fragmentation in this group and Lane (6) showed (2+) DNA fragmentation in this group .Lanes 3,4,5,6 corresponding to 15,30,45 and withdrawal periods of treatment with ecstacy $30 \mathrm{mg} / \mathrm{Kg}$ b.w.). 


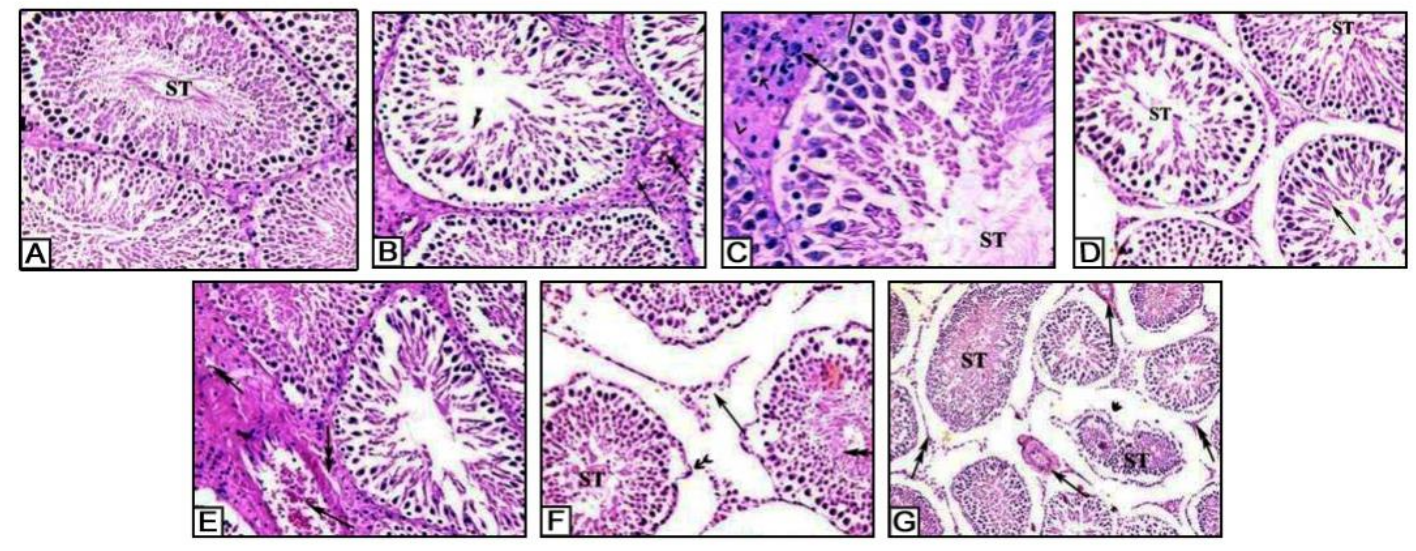

-Fig2-(A):Photomicrograph of testis tissue section of a control rat showing normal structure of seminiferous tubules(ST) and leydig cells(L).

(H\&E,X:400)

--Fig(B):Photomicrograph of testis tissue section of ecstacy treated group $(30 \mathrm{mg} / \mathrm{Kg} / \mathrm{day})$ for 15 days, showing mild to moderate proliferated leydig cells(arrow), with congested blood vessels(double arrow) and reduction in sperms and spermatids"hpospermatogensis"( double arrow head).

(H\&E,X:400)

- Fig(C):Photomicrograph of testis tissue section of ecstacy treated group $(30 \mathrm{mg} / \mathrm{Kg} / \mathrm{day})$ for 30 days, showing vaculated cytoplasm in leydig cells. Also,moderate proliferated interstitial tissue"leydig cells".

(H\&E.X:400)

-Fig(DandE): Photomicrograph of testis tissue section of ecstacy treated group $(30 \mathrm{mg} / \mathrm{Kg} / \mathrm{day})$ for 45 days, showing mild to moderate atrophy of seminiferous tubules(ST)with depletion of sperms spermatids (arrow).

(H\&E.,X:400)

Fig(F): Photomicrograph of testis tissue section of ecstacy treated group( $30 \mathrm{mg} / \mathrm{Kg} / \mathrm{day})$ for 45 days, showing mild to moderate atrophy of seminiferous tubules(ST)with depletion of sperms spermatids (arrow).

(H\&E.,X:400)

Fig $(\mathrm{G})$ : Photomicrograph of testis tissue section of ecstacy withdrawal group(W15) for 15 days, showing depletion in size of seminiferous tubules with marked irregular shape "shrinkage(ST)(double arrow head) ,together with marked reduction in inter stitial tissue(arrow) and hypo spermatogensis(double arrow) were seen.. (H\&E.,X:400) 